\title{
TEACHING MATERIALS MODEL FOLKLORE IN LEARNING INDONESIAN BASED ON THEMATIK APPROACH
}

\author{
Satinem ${ }^{1}$, Achmad HP $^{2}$ \\ ${ }^{1}$ STKIP-PGRI Libuklinggau, Indonesia \\ ${ }^{2}$ Language Teaching Study Program of Graduate Prgram of University Negeri Jakarta, Indonesia \\ 1y.sartinem@yahoo.co.id, 2achmad.hp@unj.ac.id
}

\begin{abstract}
Literature module in this research is regional literature module which is developed based on the previous module in teaching and learning Indonesia The aim of this research is to produce a model of module for Indonesia based on the thematic approach from folklore for the third grade students of elementary school in Lubuklinggau, In this research, further development was done based on teacher and students' need analysis. Research and Development (R\&D) method is used in this research. This research combined research model of Brog\& Gall and development model of Dick \& Carey. Therefore, research and development is a process of developing and validating educational product. Educational product in this research refers to the syllabus, module, and lesson plan/instructional design. Based on the data gathered from the application of developmental plan of learning model which consist of syllabus, lesson plan, limited try out test, large try out test, model effectiveness test, and module readability test, it can be stated that the teaching and learning model which is developed can increase the third grade students' achievement at elementary school in Indonesian teaching and learning with the source of regional literature.
\end{abstract}

Keywords: Indonesian Foklore; Teaching Material and Learning Model; Thematic Approach.

The material of folklore in learning Indonesia at Primary Schools contained in Garis-Garis Besar Program Pengajaran (GBPP) dan KTSP through regulation of the Minister of National Education No. 22 of 2006 should has aim "In order for the student is able to enjoy and take advantage of literary works to develop personality, broaden horizons of life, and to improve the knowledge and language skills”. Learning is carried out with due regard to the principle of utilizing natural conditions, social and cultural, as well as regional wealth (Depdiknas, 2006).

The fundamental concept from the aim of literature's learning, furthermore detailed and translated through signs curriculum's activities and also by some experts, so grow up the perception about the aim of literature's learning which the goal toward at appreciation. it has aim to inmprove the students' ability in order to appreciate literature's work (folklore)that related by excercise to deeper the students' feeling, cultur and the environment.

Literature is social's document by language. Traditional literary techniques like symbolism and spells are social because of the conventions and norms of society. Meanwhile Wellek (1976:95) said that literature is cultures' warehousee, source book history of civilization, especially the history of rise and fall of the spirit of chivalry. Therefore, by studying the literature can be found documents or social portrait. It said as social document because of literature has relation with reproduction of life that tend to mirror reality in society, whereas literature as a social portrait, literature has the ability to record signs of the times, both temporally and periodically. Based on Danandjaja (2009:1) oral literature or folklore is part of the 
culture system who inherited down orally or through an example that was followed with a gesture or reminder's help tool. According to Suwandi (1986: i-ii) oral literature or folklore is devided become 3 parts, they are: 1 ) fairytale is a story about the life of an animal or the ancient times that are illusory; 2) hypothetic is an ancient story that is related to history and 3) Guritan is the story of the origin of offspring or event that really happened and no doubt the truth because it is supported by authentic's evidence. The three types of literature give the benefit of supporting community because oral literature can pass on cultural values of the past and the present.

As documents and social portrait, literature always concerned with issues of human life contained in society in all its aspects. Thus the literary work can be seen as a mirror of people's lives past which also can describe the behavior, illustration of prevailing traditions and levels of life that has been achieved by the community in the past. Many efforts made by the developers of education in order to improve student achievement in learning Indonesian, particularly on the material folklore, by using the environment as a medium. Folklore which Submitted will cause students' interest to learn as long as they are relevant to his life story. One of the efforts of teachers to attract students in understanding folklore stories can through the recording media. This activity can be done by giving students the chance to listen to the story that is played (listening activities), followed by speaking and writing.

As an educator, the researcher intends to develop a model of instructional materials folklore in learning Indonesian that is expected to involve students actively and constructive in learning. Through learning rooted in folklore is expected to be a process of learning that is fun, creative, and certainly not boring. According to Joyce, dkk (2009:24) a model of teaching is a descriptive of learning environment, including our behavior as teaching our behavior as teachers when that model is used. The model is a conceptual framework that describes procedural systematically in organizing learning experiences to achieve the goal may be a series of approaches, strategies, methods, and techniques of learning. Thus, the model can simplify reality because reality is often too complex to be described. Complexity is unique to a particular situation, while the model can help identify things that are generic and can be applied in various contexts. Based on Robins (1996:25), "A model is an abstraction of reality; a simplified representation of some real-world phenomenon." The intent of this definition, a model is a representation of some of the phenomena that exist in the real world. So, the model is a process mindset and the components' contained therein are represented in graphic form and or narrative.

In developing the thematic models, Fogarty (1991:3) states that thematic learning model can be grouped into the model connection (connected). Fogarty argued that the mode of connectedness is an integration model internal course study. These models are significantly organizes or integrate the concepts, skills, or abilities are fostered in one subject that is associated with the concept, skills or abilities in the subject in one field of study. Linkages can be organized spontaneously or planned in advance, thus learning becomes convinced meaningful and effective. In other words, learning type of connected is learning that done by linking the subject with the next subject, linking one concept to another, linking one skill to another skill, and also relate the day's work with other day or the next day in a field of study. Model nested is the integration of the curriculum in one discipline in particular put the focus on the integration of a number of learning skills who want to be trained a teacher to the 
students in a learning unit for the achievement of learning materials. According to Fogarty study skills include thinking skills, social skills, and organizing skills. Basically the steps nested models follow three stages, namely planning, implementation, and evaluation stages. Characteristics of the subjects became the foundation for these initial activities. For example for the kind of social subjects and language skills of thinking can be combined with social skills. As for the subjects of science and mathematics can be integrated thinking skills and organizing skills.

Integrative approaches can be interpreted as an approach that unity from several aspects into one process. Integrative divided into internal course studies and between fields of study. For example, listening integrated with speaking and writing. Linguistic material integrated with language skills. Integrative between fields of study is the integration of material from several fields of study (Shambaugh, 2006:224). When teaching the sentence, the teacher does not directly handed sentences materials to students but begins with reading or other. The placement regulated is very thin. In fact, a teacher who knows how to integrate the delivery of material can bring on the students does not feel the movement of the material Integrative highly desirable in learning Indonesian. Integrating applied in accordance with the basic competencies that need to be owned by the students. The material is not separated. Teaching material is precisely the unity that needs to be packaged attractively menarik (Heaton, 1989:16). This research is very concerned about the principle of integrative in learning Indonesian which is based on folklore. Integration realized starting from the preparation of the RPP to the learning process. Teachers implementing four components of language skills with an integral.

\section{METHOD}

The research methods at this research is Research and Development. Based on Borg (1983:772) Research and Development is "A process used to develop and validate educational products”. According to Semiawan (2007:181), Research and Development (R \& D) is the border of qualitative and quantitative approaches, especially to bridge the gap between research and practice of education. Thus $\mathrm{R}$ and $\mathrm{D}$ is a process to develop and validate the educational product. Educational products referred to the research are the syllabus, lesson plans, and teaching materials. While research method used in this study with consideration of compatibility with the nature of the research to be carried out the method of Research and Development ( $\mathrm{R}$ \& D). This research combines research model Borg and Gall (1983) and the model of development of Dick \& Carey (2005:1).

Development research conducted in Lubuklinggau, the third-grade students of State Elementary School and the private sector. There are 9 research site located in Lubuklinggau. Selection of schools is done by considering the level of school with categories of high, medium, and schools with fewer categories. There are 93 elementary schools in the Lubuklinggau city with detiles 85 to State schools and 8 private schools. Of the number of existing schools is determined 9 schools as a place to take research, with details: 3 high school category, three medium, and three schools less categorized. Lubuklinggau enactment as a research based on the location of the position of developing regions folklore which is the city and county as the center spread of folklore and origin of the different areas. The story which 
development at Lubuklinggau and Musirawas in ancient times is very rapidly because it is a city located in the crossing area of Sumatra and very strategic.

The research data to model the teaching material folklore in learning Indonesian can be classified into two types, namely quantitative data and qualitative data. Quantitative data obtained through a questionnaire assessment of resource persons who have been chosen as respondents. While the qualitative data obtained through written suggestions in the column section is provided in the questionnaire, then the suggestions are there described as qualitative data.

\section{RESULTS}

In the third prototype trials conducted small groups at school with categories of high, medium, and less amounts to 27 people taken at random. This is done to look at the effectiveness of the learning model used at the time of learning. Learning is done like real state, but the number of students more diverse and represent of 9 schools to be a place of research.

Field trials stage (prototype 4) is performed on the stage of the practicalities of primary school students in the category of high, medium, and less each one class with a total of 91 students. Evaluation of learning outcomes was conducted to determine the level of competence of the students after using the learning model with a thematic approach to the material folklore in learning Indonesian. Students learn declared complete when getting average value $\geq 70$ for schools with a high category, while the KKM to school with medium and low categories, namely 65. The following is display at model teaching materials folklore in learning Indonesian with a thematic approach to the third grade elementary school students in Lubuklinggau.

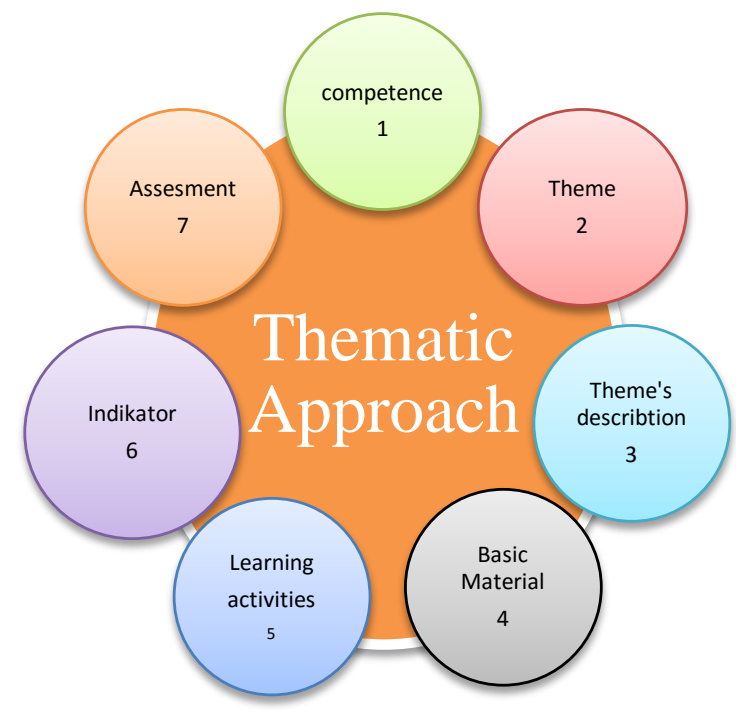

Figure 1. Display Model Instructional Materials Folklore in Learning Indonesian Based Thematic Approach 
Xaverius Elementary student learning outcomes after treatment with SPSS showed that normal distribution of data, indicated by the value Asymp. Sig (2 tailed) 0.504 at 0.05 level signify. As for the value of $\mathrm{t}-$ hit 12.00 and $1.70 \mathrm{t}-\mathrm{tab}$ to (d) 30 and $\alpha$ of 0.05 , thus it can be concluded $t-$ hit $>t-t a b$, so that Ho refused and $\mathrm{Hi}$ accepted, it means that the average value -rata mastery learning students in class III SD Xaverius after using a thematic approach based learning model is equal to 70 or more than 70 .

Next the data processing in the school category were (SD Negeri 62) as follows: normal distribution of data, indicated by the value Asymp.Sig. (2-tailed) 0.116 at significant level of 0.05 . As for the value of $\mathrm{t}-$ hit 9.624 and $1.71 \mathrm{t}-$ tab to (d) 26 and $\alpha$ of 0.05 , thus it can be concluded $\mathrm{t}-\mathrm{hit}>\mathrm{t}-\mathrm{tab}$, so Ho rejected and Hi is received, it means the average value mastery learning students in third grade primary school 62 Lubuk Kupang after using the model of learning by using a thematic approach is equal to 65 or more than 65.

Subsequent trials conducted in schools with low category (SD Negeri 20 Lubuklinggau) obtained the following results: that the normal distribution of data, indicated by the value Asymp.Sig. ( 2 - Tailed) 0.236 at significant level of 0.05 . As for the value of $\mathrm{t}$ - hit 11.476 and $\mathrm{t}$ - tabs 1.71 to (d) 24 and alpha of 0.05 , thus it can be concluded $\mathrm{t}$ - hit $>\mathrm{t}$ - tab, so Ho rejected and Hi is received, it means the average value mastery learning students in third grade primary school 20 Lubuklinggau after using a thematic approach based learning model is equal to 65 or more than 65 .

\section{DISCUSSION}

Learning model was developed using a thematic approach. Finocchiaro (1983: 37) states that in this approach the same socio-cultural theme, structural categories or learned language functions in a logical sequence always deeper. Previously learned material will be remembered until the last and integrated with new learning. This approach to development begins with determining a particular theme. Themes can be determined by negotiation between teachers and students, but can also be a way of discussion among teachers. Once the theme is agreed upon, developed sub theme with regard relation to the field of study. Of the sub theme developed students' learning activities that must to do. Learning steps thematic approach, namely: 1) preliminary research; 2) planning model development; 3) validation, evaluation and revision of the model, and 4) implementation of the model.

Preliminary research conducted to design a model development of teaching materials folklore in learning Indonesian. Here is a thematic learning design (Figure 2).

Measures undertaken at the preliminary study stage is the stage of studying literature, analysis of needs, and field studies. Analysis of the material needs of folklore in learning Indonesian is done by identifying the thematic goal of making models, identify gaps between that performed in the field with the expected, followed up on the problem-solving process, and the final step to be evaluated to determine the effectiveness and efficiency of the model applied in teaching. Analysis of the characteristics of the students performed on grade III elementary students selected as the study sample. From the analysis of the students obtained a very 
heterogeneous class. All information obtained through the provision of questionnaires to students, teachers, and principals.

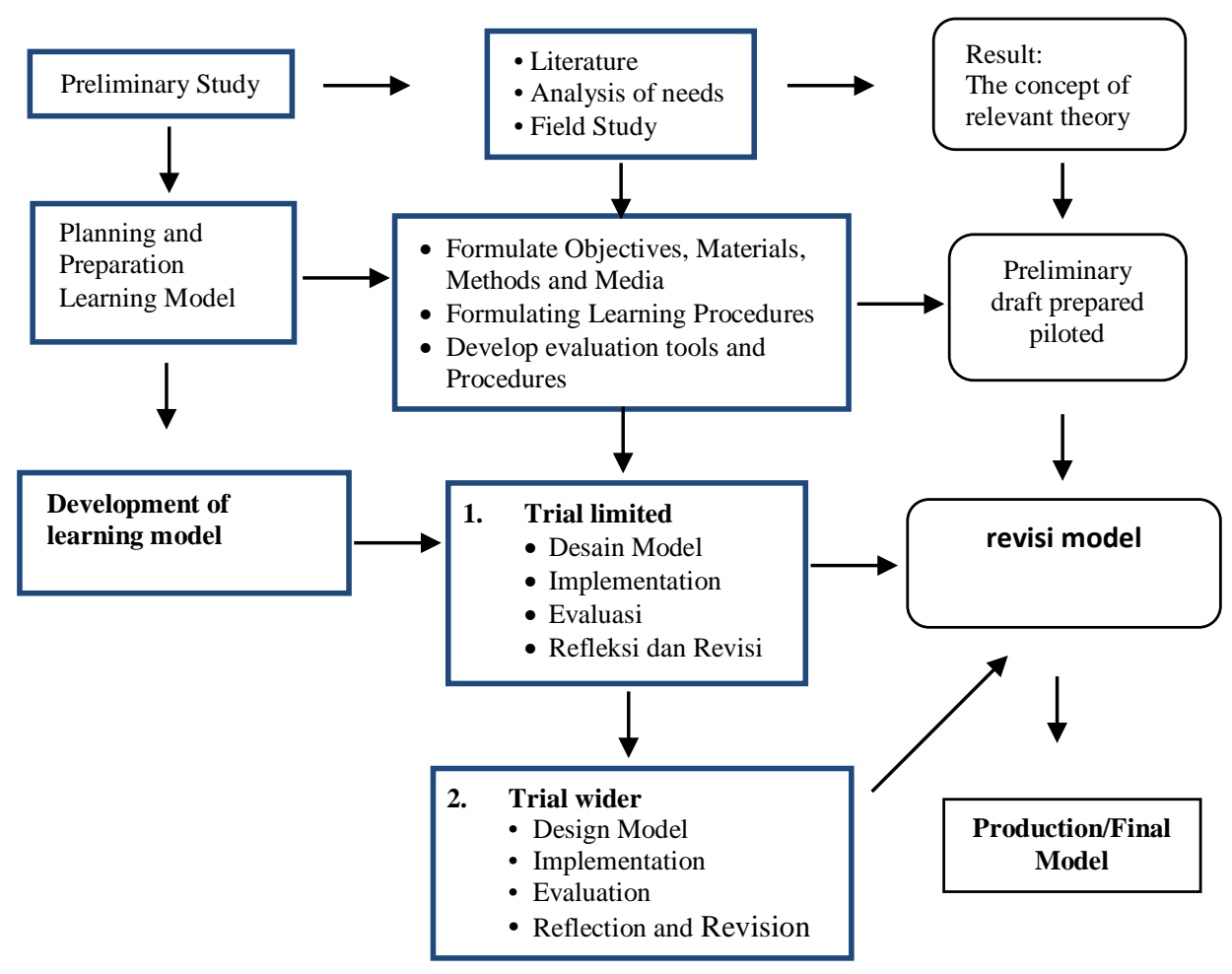

Figure 2. Design of Learning Folklore

Measures undertaken at the stage of evaluation and revision of the model in this study conducted in the form of an evaluation of each end of the lesson. Namely the evaluation phase conducted by experts who have been determined, the evaluation by the teacher, small group trial, and trials broad groups.

Phase 1 initial prototype evaluation experts to get information about the suitability of the material with the purpose of learning, the concept of truth, regency material, as well as the scope and depth of the material. Results from the 1 prototype revision to produce prototype 2 , as references for the validation of assessment friend (teacher). Once evaluated, in general students were interested and very enthusiastic especially when played recordings of folklore. Readability level students to the folklore material is also very good, they can listen to good stories can be heard and answered a variety of questions covering the four language skills.

Because of the three schools sampled in the research result $t$ is greater than table or are in critical areas , Ho is rejected, meaning that the Indonesian learning process by using a thematic approach rooted in folklore that is applied to the third grade elementary school students proved to be effective, The questionnaire was given in order to determine the needs of students related to the syllabus folklore using a thematic approach is needed at $50.00 \%$, which states needed for $41.67 \%$, and which states are less needed at 8:33\%. None of the teachers also choose alternative answers are not needed and very unnecessary. From the description of the results of the analysis of the needs of the syllabus can be concluded that the Indonesian learning 
syllabus rooted in folklore has become the need of the students and teachers are expected to be realized in the curriculum. Communicative - integrative approach in learning Indonesian is written clearly on the syllabus which is used as a model.

From the description of the results of the analysis of the needs of the syllabus can be concluded that the learning syllabus folklore has become the needs of students and teachers are expected to be realized in the curriculum are local. Communicative - integrative approach in learning Indonesian is written clearly on the syllabus which is used as a model.

\section{CONCLUSION}

Conclusion end of the study, the first, the results of the analysis of needs, from 9 respondents third grade elementary school teachers, principals, and users folklore hopes that folklore is in Lubuklinggau used as learning materials Indonesian with 2 hours of time each week, or be given equal time with another subject. Based on the needs analysis and observation, so it is developing teaching materials sourced in Indonesian folklore based on a thematic approach for elementary school third grade students in Lubuklinggau. The model is arrange based on the students and teachers' needs, with the following characteristics: 1) The learning process folklore integrative given by integrating the four components of language skills, the skills of listening, speaking, reading, and writing skills in an activity that is based on the chosen theme; 2) the process of learning the Indonesian based on folklore allows students more actively so as to communicate; 3) learning is able to provide an atmosphere that is fun and not boring; 4) learning folklore based on the themes contained in the curriculum and the curriculum in 2013; 5) learning process that is able to explore the values of the local culture in Lubuklinggau; 6) learning gives students the concept of what is learned can be meaningful for him; 7) learning as a whole is not given entrenched that the students' understanding will be even easier in short time; 8) the learning's value include assessment of learning processes and outcomes of learning which includes cognitive, affective, and psychomotor; 9) learning that allows for the cultivation of moral values which are positive for the mental development of students; 10) Learning folklore that has a specific area that certainly not shared by other regions.

Secondly, all the materials in the teaching materials developed by integrating the four components of language skills, the skills of listening, speaking, reading, and writing skills. Topics raised by the theme of the story contained in the curriculum and the curriculum in 2013, namely social themes, compliance, honest behavior, responsibility, and the theme of indulgence.

Third, the results of the third evaluation experts showed that the models of teaching materials folklore in learning Indonesian is based on a thematic approach developed meet the relevant eligibility requirements and are used in terms of aspects 1) teaching materials; 2) theme; 3) the design of instructional materials; 4) objectives, evaluation/training; and 5) benefits.

Fourth, the results of the perception of three teachers representing each school categories and the assessment criteria used to convert the answer indicate that the perception of Indonesian teacher who teaches folklore at Lubuklinggau amounted to 2.74 with both categories. Thus, the empirical models of teaching materials folklore 
in Indonesian language learning development include decent and relevant for use in learning Indonesian elementary school third grade students in Lubuklinggau. Fifth, test results of product effectiveness models of teaching materials produced through experiments prove that the t-test of the teaching materials developed very significant. Because of the three schools sampled in the study results obtained $t$ count $>t$ table or are in critical areas, Ho is rejected, meaning that the learning process folklore using a thematic approach is applied to the third grade elementary school students proved effective.

\section{REFERENCES}

Borg and Gall. (1983). Educational Research: An Introduction. London.

BSNP. (2008). Model Silabus Tematik Kelas III. Jakarta: Pusat Bahasa.

Danandjaja, James. (2002). Foklor Indonesia: Jakarta.

Dick, Walter. Lou Carey dan James O Carey. (2005). The Systematic Design of Instruction. Boston: Pearson.

Fogarty, Robin. (1991). The Mindful School Integrate the Curricula: New York City: Columbia University Teacher College.

Finocchiaro, Marry. (1983). The Functional-National Approach. Oxford University Press.

http://edubisnis.com/pendekatan-integratif/ (diakses 7 Juli 2014)

Heaton, J.B. (1989). Writing Engglish Language Test: London and New York.

Joyce, Bruce and Marsha Well and Emily Calhoun. (2009). Models of Teaching: United States of America Pres.

Neal, Shambaugh dan Susan S. Magliaro. (2006). Instructional Design: A Sistematic Approach for Reffective Practice USA Pres.

Robins, Stephen P. (1996). Organizational Behavior: Concepts, Controversies, Applications. New York: Prentice Hall, Inc.

Semiawan, Conny R. (2007). Catatan Kecil tentang Penelitian dan Pemngembangan Ilmu Pengetahuan. Jakarta: Kencana Prenada Media Grup.

Suwandi, Syam. (1986). Kehidupan Masyarakat, Upacara Adat, Sejarah dan Legenda Daerah Musirawas.

Wellek Rene, Theory of Literatur. (1976). Penguin University Books: London. 